\title{
EDITORIAL
}

\section{0 years of communicating facts and figures}

I Steffens ${ }^{1}$

1. European Centre for Disease Prevention and Control (ECDC), Stockholm, Sweden

Correspondence: Ines Steffens (ines.steffens@ecdc.europa.eu)

Steffens I. 20 years of communicating facts and figures. Euro Surveill. 2016;21(48):pii=30415. DOI: http://dx.doi.org/10.2807/1560-7917.ES.2016.21.48.30415

Article published on 01 December 2016

Since 1995, when a first pilot issue was published, Eurosurveillance has provided the European public health community with a platform to exchange relevant findings on communicable disease surveillance, prevention and control. From the outset, the journal has been open access and has not charged article processing costs.

In 2016, we celebrate 20 years of regular publication. A glimpse at the Eurosurveillance archives demonstrates how the journal has matured over the years in terms of format and content. It shows, for example, the merging of the formerly weekly and monthly issues, acceptance of the 'weekly' for indexing in PubMed/MEDLINE and the evolution from a print and online journal to a full online journal and a gradual geographical expansion of the origin of published articles.

However, already from the start, topics covered were remarkably similar to those that are high on the public health agenda today. One of the articles in the pilot issue in 1995 gave an overview of immunisation schedules in Europe [1], a topic still of interest nowadays. Our aim to provide insightful and balanced information on vaccination was shown after the later retracted publication by Wakefield et al. that included subsequently falsified claims of an association of measles mumps and rubella vaccines with autism [2]. Just one week afterwards, Eurosurveillance ran a commentary in its weekly edition, followed, two months later, by one entitled 'Further evidence that MMR vaccine, inflammatory bowel disease, and autism are not linked' [3,4]. The public health challenges that Europe faces in reaching the measles elimination goal in Europe were marked in a 'Spotlight on measles' series on ongoing outbreaks and their implications [5].

Since the early days of the journal, surveillance network outputs and outbreak reports have been regular content [6], with topics such as HIV/AIDS and other sexually transmitted infections [7-9], emerging (vectorborne) diseases [10], influenza [11], antimicrobial resistance [12], tuberculosis [13,14] and food- and waterborne diseases [15]. As illustrated by the following subjective selection of articles from the past two decades, public health events and other topics with general public health relevance have also been covered, such as the preparedness for bioterrorism after the 11 September attacks in 2001 in the United States [16], the outbreak of severe acute respiratory syndrome (SARS) [17], the 2009 influenza pandemic [18], the emergence of Middle East respiratory syndrome (MERS) [19], as well as the setup of the European Programme for Intervention Epidemiology Training (EPIET) programme [20] and discussions about establishing a European Centre for Disease Control [21].

Rapid communications were an early feature for the journal at a time when rapid processing of articles was not a common element of scientific journals. The evolution, growth and opportunities offered by the Internet facilitated timely communication and fast turnaround times tremendously. The initially short news-like items are the element of the journal that has most evolved. Today, rapid communications are well-recognised short scientific dispatches. Several of them are among our most highly cited articles, but more importantly, their value has been in their impact on public health practice.

While we have been able to present 'firsts' on several occasions [22,23] and track epidemics and emerging diseases in a timely manner [24], we are publishing an increasing number of (systematic) reviews to provide sound evidence and support for decisionmaking [25].

Working with Eurosurveillance is rewarding. The journal has many supporters and collaborators in Europe and beyond whom we are not able to name individually. We would like to express our gratitude to them and also 
thank our board members, colleagues and publisher wholeheartedly for their continued support. Our 2oth anniversary is a reason to celebrate. We marked the occasion on Wednesday 30 November with a lunchtime seminar '20 years of communicating facts and figures in a changing environment', held on the margins of the European Scientific Conference on Applied Infectious Diseases Epidemiology (ESCAIDE). Two eminent speakers, David Heymann and Lawrence Madoff, highlighted changes in sharing information about communicable diseases from a public health perspective over the past 20 years. In addition, we present this selection of articles as a snapshot of the journal's publications and evolution. The topics covered match those that have remained relevant over two decades and we hope our readers will enjoy browsing through this compilation.

\section{References}

1. Guérin N, Roure C. Immunisation schedules in the countries of the European Union.Euro Surveill. 1995;0(0):5-7. Available from: http://www.eurosurveillance.org/ViewArticle. aspx?Articleld=201PMID: 12631752

2. The Editors of The Lancet. Retraction--Ileal-lymphoid-nodular hyperplasia, non-specific colitis, and pervasive developmental disorder in children.Lancet. 2010;375(9713):445. DOI: 10.1016/ S0140-6736(10)60175-4 PMID: 20137807

3. Miller E. Reported association between measles, mumps, and rubella (MMR) vaccine, autism, and bowel syndrome. Euro Surveill. 1998;2(10):1247. Available from: http://www. eurosurveillance.org/ViewArticle.aspx?Articleld=1247

4. Pebody RG. Further evidence that MMR vaccine, inflammatory bowel disease, and autism are not linked.Euro Surveill. 1998;2(19):1219. Available from: http://www.eurosurveillance. org/ViewArticle.aspx?Articleld=1219

5. Slaymaker E, Joseph C, Bartlett CL. Travel associated legionnaires disease in Europe: 1997 and 1998.Euro Surveill. 1999;4(11):120-4. Available from: http://www.eurosurveillance. org/ViewArticle.aspx?Articleld=62PMID: 12631885

6. Rogalska J, Santibanez S, Mankertz A, Makowka A, Szenborn L, Stefanoff P. Spotlight on measles 2010: An epidemiological overview of measles outbreaks in Poland in relation to the measles elimination goal.Euro Surveill. 2010;15(17):19549. Available from: http://www.eurosurveillance.org/ViewArticle. aspx?Articleld=19549PMID: 20460084

7. Nicoll A. Global HIV epidemic.Euro Surveill. 1998;2(26):1196. Available from: http://www.eurosurveillance.org/ViewArticle. aspx?Articleld $=1196$

8. Infuso A, Hamers FF, Downs AM, Alix J. HIV reporting in western Europe: national systems and first European data. Euro Surveill. 2000;5(2):pii=29. Available from: http://www. eurosurveillance.org/ViewArticle.aspx?Articleld $=29$

9. Velicko I, Kühlmann-Berenzon S, Blaxhult A. Reasons for the sharp increase of genital chlamydia infections reported in the first months of 2007 in Sweden.Euro Surveill. 2007;12(10):E5-6. Available from: http://www.eurosurveillance.org/ViewArticle. aspx?Articleld=737PMID: 17997928

10. Zeller H, Zientara S, Hars J. West Nile outbreak in horses in Southern France: September 2004. Euro Surveill. 2004;8(41):2564. Available from: http://www.eurosurveillance. org/ViewArticle.aspx?Articleld $=2564$

11. Watson J. Four cases of $\mathrm{H}_{5} \mathrm{~N}_{1}$ influenza in Hong Kong. Euro Surveill. 1997;1(33):1010. Available from: http://www. eurosurveillance.org/ViewArticle.aspx?Articleld=1010

12. van den Hof $S$, van der Kooi $T$, van den Berg R, Kuijper EJ, Notermans DW. Clostridium difficile PCR ribotype 027 outbreaks in the Netherlands: recent surveillance data indicate that outbreaks are not easily controlled but interhospital transmission is limited.Euro Surveill. 2006;11(1):E060126.2.PMID: 16801713

13. Handysides S. Surveillance of tuberculosis in Europe: first data emerge from “EuroTB”. Euro Surveill. 1997;1(27):pii=1031. Available from: http://www.eurosurveillance.org/ViewArticle. aspx?Articleld $=1031$

14. Ködmön C, Zucs P, van der Werf MJ. Migration-related tuberculosis: epidemiology and characteristics of tuberculosis cases originating outside the European Union and European
Economic Area, 2007 to 2013.Euro Surveill. 2016;21(12):30164. DOI: 10.2807/1560-7917.ES.2016.21.12.30164 PMID: 27039665

15. de Valk H, Jacquet C, Goulet V, Vaillant V, Perra A, Simon F, et al. , Listeria Surveillance Feasibility Study Participants. Surveillance of listeria infections in Europe. Euro Surveill. 2005;10(10):251-5. Available from: http://www. eurosurveillance.org/ViewArticle.aspx?Articleld=572PMID: 16282642

16. Coignard B, Members of the Eurosurveillance editorial board. Bioterrorism preparedness and response in European public health institutes.Euro Surveill. 2001;6(11):159-66. Available from: http://www.eurosurveillance.org/ViewArticle. aspx?Articleld=383PMID: 11891386

17. Radun D, Niedrig M, Ammon A, Stark K. SARS: retrospective cohort study among German guests of the Hotel ' $M$ ', Hong Kong.Euro Surveill. 2003;8(12):228-30. Available from: http://www.eurosurveillance.org/ViewArticle. aspx?Articleld=436PMID: 14724331

18. Surveillance Group for New Influenza $A\left(\mathrm{H}_{1} \mathrm{~N}_{1}\right)$ Virus Investigation and Control in Spain. New influenza $A\left(\mathrm{H}_{1} \mathrm{~N}_{1}\right)$ virus infections in Spain, April-May 2009. Euro Surveill. 2009;14(19):19209. Available from: http://www. eurosurveillance.org/ViewArticle.aspx?Articleld=19209PMID: 19442404

19. Perera RA, Wang P, Gomaa MR, El-Shesheny R, Kandeil A, Bagato 0 , et al. Seroepidemiology for MERS coronavirus using microneutralisation and pseudoparticle virus neutralisation assays reveal a high prevalence of antibody in dromedary camels in Egypt, June 2013. Euro Surveill. 2013;18(36):20574. DOI: $10.2807 / 1560-7917 . E S 2013.18 .36 .20574$ PMID: 24079378

20. Giesecke J, Moren A, Rowland M, Van Loock F. The European Programme for Intervention Epidemiology Training.Euro Surveill. 1996;1(4):30-1. Available from: http://www. eurosurveillance.org/ViewArticle.aspx?Articleld=171PMID: 12631845

21. Pritchard L. European Commissioner again pledges European centre for disease control by 2005 . Euro Surveill. 2002;6(40):1888. Available from: http://www.eurosurveillance. org/ViewArticle.aspx?Articleld $=1888$

22. Frank C, Faber MS, Askar M, Bernard H, Fruth A, Gilsdorf A, et al. , HUS investigation team. Large and ongoing outbreak of haemolytic uraemic syndrome, Germany, May 2011.Euro Surveill. 2011;16(21):19878. Available from: http://www. eurosurveillance.org/ViewArticle.aspx?Articleld=19878PMID: 21632020

23. Lópaz MA, Amela C, Ordobas M, Domínguez-Berjón MF, Álvarez C, Martínez M, et al. , Working group of Ebola outbreak investigation team of Madrid. First secondary case of Ebola outside Africa: epidemiological characteristics and contact monitoring, Spain, September to November 2014. Euro Surveill. 2015;20(1):21003. DOI: $10.2807 / 1560-7917 . E S 2015 \cdot 20.1 .21003$ PMID: 25613651

24. Roth A, Mercier A, Lepers C, Hoy D, Duituturaga S, Benyon $E$, et al. Concurrent outbreaks of dengue, chikungunya and Zika virus infections - an unprecedented epidemic wave of mosquito-borne viruses in the Pacific 2012-2014. Euro Surveill. 2014;19(41):20929. DOI: 10.2807/1560-7917. ES2014.19.41.20929 PMID: 25345518

25. Coque TM, Baquero F, Cantón R. Increasing prevalence of ESBL-producing Enterobacteriaceae in Europe.Euro Surveill. 2008;13(47):19044. Available from: http://www. eurosurveillance.org/ViewArticle.aspx?Articleld=19044PMID: 19021958

\section{License and copyright}

This is an open-access article distributed under the terms of the Creative Commons Attribution (CC BY 4.0) Licence. You may share and adapt the material, but must give appropriate credit to the source, provide a link to the licence, and indicate if changes were made.

This article is copyright of the European Centre for Disease Prevention and Control, 2016. 